\title{
SURVEI EFEKTIVITAS LATIHAN PADA EKSTRAKURIKULER SEPAK BOLA DI SMP NEGERI 4 DEDAI
}

\author{
Oky Anggia, Isti Dwi Puspita Wati, Andika Triansyah \\ Program Studi Pendidikan Jasmani FKIP Untan Pontianak \\ Email:oky.anggia79@gmail.com
}

\begin{abstract}
The purpose of this study was to determine how much the effectiveness of exercise on the extracurricular soccer in SMP Negeri 4 Dedai. The method used in this research was quantitative descriptive with a from of research whith method of survey. The population in this research was the process of exercise extracurricular soccer in SMP Negeri 4 Dedai the academic year 2018/2019. And sample is the process of exercise on the extracurricular soccer even semester of the academic year 2018/2019. Data collection techniques used incidental sampling method, a tool for collecting data by observing and recording exercise activities from time to time using stationery. From the results of the research conducted, it can be concluded that the results of the effective average value of students in the first meeting were 15.6 (97.9\%), the second meeting was 19.5 (97.9\%), the third meeting was 13.3 (95.1\%) the fourth meeting 19.7 (98.7) fifth meeting 15.6 (97.9\%) sixth meeting 11.9 (99.4\%) with a total overall score of 15.9 with a percentage of $97.8 \%$ and included in the percentage category which is very effective.
\end{abstract}

\section{Keywords: efektiveness of training, extracurricular, soccer}

\section{PENDAHULUAN}

Olahraga adalah salah satu bentuk dari upaya peningkatan kualitas manusia Indonesia yang di arahkan pada pembentukan watak dan kepribadian, disiplin dan sportivitas yang tinggi, serta peningkatan prestasi yang dapat membangkitkan rasa kebanggaan Nasional. Kegiatan olahraga mencakup berbagai macam cabang seperti atletik, permainan, olahraga air, dan olahraga beladiri. Olahraga permainan yang makin banyak banyak di gemari oleh masyarakat terutama di kalangan pelajar dan mahasiswa adalah olahraga sepak bola.

Olahraga sepak bola merupakan olahraga yang merakyat. Hampir dipastikan masyarakat dunia sangat mengenal olahraga sepak bola. Seandainya sebagian tidak menggemari atau tidak dapat memainkannya, minimal mereka mengetahui tentang olahraga ini. Sepak bola adalah olahraga yang paling populer di dunia. Semua kalangan baik tua dan muda bahkan tanpa membedakan laki-laki dan perempuan sangat menggemari olahraga ini.

Menurut Rahmani Mikanda (2014: 99) "sepak bola merupakan permainan yang dimainkan oleh 11 orang pemain dan dilakukan dilapangan yang sangat luas". Dalam sepak bola, keterampilan teknik dasar sangat penting untuk di kuasai pemain. Bedasarkan pendapat Wildan Herdiansyah (2011 : 18) "keterempilan yang utama adalah menguasai teknik-teknik dasar sepak bola". Teknik tersebut yaitu mengumpan dan menerima (passing dan receving), menembak (shooting), mengontrol bola dengan berbagai anggota badan, melindungi bola dan menggiring bola (dribbling).

Rahmani Mikanda (2014: 99) bahwa "sepakbola merupakan permainan yang dimainkan oleh 11 orang pemain dan dilakukan dilapangan yang sangat luas". Wildan Herdiansyah (2011: 18) "keterempilan yang utama adalah menguasai teknik-teknik dasar 
sepak bola. Teknik tersebut yaitu mengumpan dan menerima (passing dan receving), menembak (shooting), mengontrol bola dengan berbagai anggota badan, melindungi bola dan menggiring bola (dribbling)".

Fasilitas permainan sepak bola antara lain adalah lapangan menurut Rachmat fadillah (2009: 6) menyatakan bahwa "sepakbola merupakan permainan yang dimainkan di atas lapangan yang luas berbentuk persegi panjang dengan ukuran panjang 100-110m dan lebar 64m-75m". Lapangan dibatasi oleh garis putih dengan ukuran $12 \mathrm{~cm}$, hal tersebut dimaksudkan untuk membedakan daerah dalam lapangan dan daerah luar lapangan. Dan di tengah-tengah lapangan terdapat lingkaran dengan jari-jari $9,15 \mathrm{~m}$. Gawang gawang dalam permainan sepak bola adalah tujuan pemain dalam setiap pertandingan" Rachmat Fadillah (2009: 7). Setiap pemain berusaha untuk memasukan bola ke dalam gawang lawan sebanyak-banyaknya dan berusaha semaksimal mungkin agar gawangnya sendiri tidak kemasukan. Terdapat dua gawang yang ditempatkan di garis akhir masing daerah yang saling berhadapan. Gawang berbentuk persegi panjang dengan ukuran panjang $7,32 \mathrm{~m}$ dan tinggi $2,44 \mathrm{~m}$ dan dengan bahan metal agar tidak berbahaya bagi pemain. Bola yang dipakai dalam setiap pertandingan harus sesuai dengan standar FIFA yang telah diuji sebelumnya. Menurut Rachmat Fadillah (2009: 8) "dalam permainan sepak bola, bola yang dipergunakan berbentuk bulat dengan bahan terbuat dari kulit dari bahan yang sejenis". Keliling bola berkisar $68-70 \mathrm{~cm}$, dengan berat berkisar dari 410gram-450gram dan dengan tekanan udara dalam bola 0,6-1,1 atmosfer.

Latihan merupakan unsur penting dalam pencapaian prestasi, tanpa latihan prestasi tidak akan bisa di ciptakan. Menurut sukadiyanto (2011 : 1) "latihan merupakan suatu proses perubahan ke arah lebih baik, yaitu untuk meningkatkan kualitas fisik, kemampuan fungsional peralatan tubuh dan kualitas psikis anak latih".

Latihan harus dilakukan 'terus menerus dengan beban yang meningkat dan terukur, pengertian latihan adalah "aktivitas untuk meningkatkan keterampilan atau kemahiran berolahraga dengan mengunakan berbagai peralatan sesuai dengan kebutuhan dan tujuan berolahraga" Sukadiyanto (2011 : 5). Latihan merupakan aktifitas fisik yang menimbulkan reaksi yang baik bagi tubuh. Latihan sebagai suatu proeses penyempurnaan kemampuan berolahraga yang berisi materi teori dan praktek, menggunakan metode, dan aturan pelaksanaan dengan pendekatan ilmiah, memakai prinsip pendidikan yang terencana dan teratur, sehingga tujuan latihan dapat tercapai pada waktunya.

Latihan adalah proses yang sistematis dari berlatih atau bekerja, yang dilakukan secara berulang-ulang, dengan kian hari kian menambah beban latihan atau pekerjaanya". Sedangkan menurut Khoiril Anam, (2013: 81) bahwa latihan merupakan aktivitas yang bertujuan untuk meningkatkan keterampilan (kemahiran) dalam berolahraga dengan menggunakan berbagai peralatan sesuai dengan tu- juan latihan yang hendak dicapai". Jadi, latihan adalah suatu kegiatan yang disusun secara sistematis yang dapat berupa kegiatan fisik atau yang dapat mengasah kemampuan yang berdasarkan pendekatan ilmiah untuk mencapai tujuan tertentu.Latihan merupakan proses yang berulang dan meningkat guna meningkatkan potensi dalam rangka mencapai prestasi yang maksimal, atlet mengikuti program latihan jangka panjang untuk meningkatkan kondisi jiwa dan raga untuk berkompetisi dalam sebuah penampilan.

Komponen latihan yang harus di pahami menurut Budiwanto (2012: 28) "adalah volume, itensitas, densitas, dan kompleksitas, recovery latihan". menjelaskan bentuk latihan beban sebagai berikut: Volume adalah kualitas beban pelatihan yang dinyatakan dengan satuan jarak total waktu pelatihan, jumlah elemen pelatihan, jumlah set dan sebagainya. Intensitas adalah kualitas beban pelatihan yang menunjukan kadar tingkat pengeluaran energy atlit dalam melakukan aktifitas fisiknya. Recorvery adalah waktu yang digunakan untuk pemulihan tenaga kembali antara satu elemen beban pelatihan berikutnya. Repetisi adalah ulangan gerak beberapa kali atlit melakukan setiap kali giliran. Frekuensi adalah berapa kali program pelatihan dilakukan setiap harinya setiap minggu. Durasi 
adalah lama pelatihan dalam satu sesi pelatihan atau waktu total rangsangan motorik dengan beban pelatihan dalam satu unik pelatihan. Irama adalah ritme atau tempo beban pelatihan yang berhubungan dengan tinggi rendahnya intesitas dan berat ringannya beban pelatihan dalam satu unik pelatihan.

Berdasarkan wawancara kepada pelatih ekstrakulikuler disekolah, pelatih terkadang telat datang dikarenakan mempunyai kesibukan yang lain, pada saat pelatih datang banyak siswa yang sudah bermain bebas sehingga membuat siswa tersebut kelelahan sebelum melakukan latihan, dan akhirnya membuat latihan semakin tidak efektif.

Dari hasil observasi yang sudah di lakukan di SMP Negeri 4 Dedai di ketahui bahwa terdapat dua ekstrakulikuler yaitu sepak bola dan bola voli. SMP Negeri 4 dedai sering mengikuti kejuaraan sepak bola di tingkat kecamatan maupun kabupaten. Di ajang resmi ataupun turnamen yang diadakan suatu desa yang pesertanya kelompok usia pelajar SMP.

Regenerasi dari waktu ke waktu, banyak siswa kelas 1 yang baru masuk ke SMP dan pastinya belum terlalu memahami tentang teknik dasar sepak bola. Tidak hanya itu, siswa kelas 2 SMP yang mengikuti ekstrakulikuler sepak bola ini juga terkadang masih kebingungan dalam melakukan teknik dasar sepak bola.

Latihan dilaksanakan hari kamis dan sabtu pada jam 15.00-16.30. Latihan biasanya dilaksanakan di halaman sekolah dan lapangan sepak bola di desa Lundang. Tahap pertama Latihan dimulai dengan berbaris, berdoa, dan penjelasan dari pelatih. Tahap kedua pemanasan dan jogging keliling lapagan total waktu 20 menit. Tahap ketiga siswa melakukan passing dengan jarak dekat dan jauh, latihan mengontrol bola, heading, dan game kucing-kucingan total waktu 25 menit. Tahap ke empat melakukan teknik permainan seperti pemain tengah dan depan melawan pemain belakang dan penjaga gawang total waktu 15 menit. Tahap ke lima bermain gawang dua di mana setiap posisi di pilih oleh pelatih dan kedua tim saling berlawanan, total waktu 20 menit, 10 menit terakhir melakukan pendinginan dan doa untuk kembali ke rumah masing-masing.
Penyusunan program latihan an pelaksanaan latihan harus sesuai. Pelaksanaan latihan haruslah efektif dan efisien. Effisiensi suatu program latihan fisik merupakan hasil manipulasi (1) intensitas, (2) volume, dan (3) densitas.

Bompa (1994) mengungkapkan bahwa "intensitas latihan dapat diartikan sebagai kualitas beban (ringan, sedang, berat atau low moderate, sub maxsimal, super maxsimal)". "merupakan ukuran dari kualitas latihan meliputi, kinerja maksimum, detak jantung maksimal, dan kadar Vo2 max" Djoko pekik (2002 : 53). Sedangkan menurut Zafar siddik (2006 : 98) " intensitas latihan menunjuk pada persentase beban dari kemampuan maksimalnya". Jadi intensitas latihan adalah "kualitas beban pelatihan yang menunjukan kadar tingkat pengeluaran energy atlit dalam melakukan aktifitas fisiknya".

Penilaian aktivitas neomuscular akan didikte oleh beban eksternal, pencapaian kecepatan, jumlah kelelahan yang berkembang, dan jenis latihan yang dikerjakan. Faktor tambahan untuk mempertimbangkan adalah ketegangan pisikologis dari sebuah latihan. Aspek psikologis dari sebuah latihan, bahkan yang dihadapkan pada tegangan fisik yang rendah, dapat memiliki intensitas dengan tingkat tinggi, yang mana dinyatakan sebagai hasil dari konsentrasi dan tekanan psikologis. Sebagai contoh, dengan latihan yang dilakukan terhadap suatu hambatan atau pada tingkat percepatan yang tinggi, intensitas latihan dapat diukur sebagai persentase dari penampilan terbaik, yang kemudian penampilanterbaik dianggap sebagai intensitas maksimum. Contohnya seorang atlit menyelesaikan lari $100 \mathrm{~m}$ dalam 10 detik, jika atlit dapat menghasilkan kecepatan yang lebih tinggi dengan jarak yang lebih pendek, maka intensitasnya akan di pertimbangkan sebagai super maksimal karena lebih dari $100 \%$ percepatan maksimal. Intensitas dan volume latihan saling berkaitan terbalik di dalam banyaknya kejadian yang terjadi, seperti contoh : ketika intensitas latihan adalah tinggi, volume latihan biasanya rendah. Strategi untuk perubahan dari intensitas latihan adalah, meningkatkan kecepatan gerakan pada jarak 
yang diberikan atau ketangkasan atau tempo dari pelaksanaan ulangan, meningkatkan beban dalam latihan, dan meningkatkan keluaran power dan aktivitas latihan.

Menurut Djoko pekik (2002: 53) "volume merupakan ukuran kuantitas dalam latihan, misalnya : waktu tempuh, jarak tempuh, jumlah beban, dan jumlah repetisi-se-seri". Sedangkan menurut bompa (1994) "volume latihan dapat berupa durasi, jarak tempuh, dan jumlah pengulangan atau repetisi”. Zafar siddik (2006: 98) mengungkapkan bahwa "volume menunjukan jumlah pembebanan dengan satuan kilo meter, meter, kilogram, dan waktu dalam menit atau detik". Volume latihan kadangkadang secara kurang tepat disebut dengan durasi latihan, menyertakan bagian integral sebagai berikut : Waktu Atau durasi latihan, Cakupan jarak atau beban volume dalam latihan menggunakan resistan (beban volume $=$ sets $\mathrm{x}$ repetisi $\mathrm{x}$ hambatan dalam $\mathrm{kg}$ ). Jumlah repitisi dari sebuah exercise atau elemen teknik yang dilaksanakan oleh atlet pada saat itu.

Waktu menjadi suatu bilangan pembagi untuk kebanyakan cabang olahraga, walaupun ungkapan volume yang sesuai mungkin suatu faktor waktu dan jarak, seperti lari $12 \mathrm{~km}$ dalam waktu 60 menit. Peningkatan jumlah sesi latihan dalam 1 hari juga muncul untuk menawarkan manfaat fisiologis. Kemampuan atlit untuk memulihkan diri dari volume latihan adalah faktor uang paling penting yang digunakan dalam rencana latihan. Atlet terlatih dapat menoleransi volume latihan yang tinggi karena mereka dapat memulihkan diri secara lebih cepat dari beban latihan. "jadi volume latihan adalah kuantitas banyaknya beban latihan yang diberikan dan materi latihan yang dilakukan secara aktif". Dengan contoh latihan yang berlangsung dengan lama tetapi di dalam latihan itu sendiri terasa hampa dengan materi latihan yang kurang, dan sebaliknya latihan berlangsung singkat tetapi materi latihannya banyak.

Densitas latihan menurut Djoko pekik (2002: 53) "merupakan ukuran derajat kepadatan latihan yakni perbandingan antara kerja dengan istirahat". Lalu Sukadiyanto (2011: 31) menyatakan, "densitas merupakan ukuran yang menunjukan derajat kepadatan waktu perangsangan (lamanya pembebanan)". "Densitas latihan dapat di definisikan sebagai frekuensi atau distribusi sesi latihan atau frekuensi dimana seorang atlit melaksanakan satu rangkaian pengulangan dari kerja per unit waktu" Johansyah lubis (2013). Sukadiyanto (2011: 31) menyatakan, "densitas merupakan ukuran yang menunjukan derajat kepadatan waktu perangsangan (lamanya pembebanan)". Dengan demikian densitas berkaitan dengan suatu hubungan yang dinyatakan dalam satuan waktu antara kerja dan istirahat. Densitas yang cukup akan menjamin efisiensi latihan, sehingga menghindarkan atlet dari kelelahan yang berlebihan. Sedangkan penerapan di lapangan masih belum bisa di katakan efektif karna beberapa faktor yang telah di uraikan di atas.

Densitas latihan dapat di bilang sebagai hubungan yang dinyatakan dalam unit waktu antara kerja dan istirahat dari latihan". Sangat sulit untuk menghitung jumlah waktu optimal yang dibutuhkan antara berbagai sesi latihan ( didalam latihan harian ) karena banyak faktor yang dapat berperan pada tingkat istirahat atlit. Intensitas dan volume latihan memainkan peranan utama dalam menentukan jumlah waktu yang dibutuhkan sebelum sesi latihan yang lain dikerjakan. Semakin besar pula jumlah waktu yang di butuhkan untuk istirahat sebelum persiapan atau kapasitas peformance diganti. Faktor-faktor tersebut semua bisa mempengaruhi kemampuannya untuk pulih. Johansyah lubis (2013) "Sebagai contoh katakan bahwa volume interval istirahat adalah 26 menit dan beban absolut adalah 102 menit. Maka densitas absolut dapat dihitung: perhitungan ini menandakan bahwa densitas absolut latihan adalah $74,5 \%$. Karna densitas latihan adalah faktor dari intensitas, indeks densitas absolut bisa dipertimbangkan sebagai densitas medium. Menentukan densitas absolut dapat berguna untuk menetapkan sesi latihan yang efektif.

Efektivitas dan efisien saling berhubungan. Yang dimaksudkan Efektivitas latihan adalah proses dari berlatih yang dilakukan berulangulang untuk mencapai suatu target dengan tepat sasaran, sedangkan efisien dalam latihan bisa di katakan pengoptimalan waktu atau hemat waktu 
dalam melakukan peroses latihan tetapi, meskipun dengan waktu yang hemat, materi dan tujuan itu sendiri tersampaikan.

Dalam latihan yang baik seharusnya sudah tersusun dengan metode yang sistematis, dengan komponen intensitas, volume, dan densitas latihan yang jelas. Ekspestasi seharusnya menu dan program latihan sudah di atur sedemikian rupa seperti melatih taktik, teknik, kekuatan, kelentukan, dan daya tahan. Seperti contoh latihan dengan durasi 90 menit, Tahap 1 : "Pemanasan" dengan melakukan pemanasan statis dan dinamis 10 menit, dan lari-lari kecil 5 menit. Tahap 2 "Teknik" melakukan passing, dan controling yang dilakukan dengan berbagai variasi selama 20 menit, dilanjutkan istirahat minum 5 menit. Selanjutnya menggiring bola, menyundul bola selama 20 menit, Tahap 3 "Taktik" taktik individu intersep dan gerak tipu 10 menit, taktik tim man to man dalam menyerang dan bertahan 15 menit. Tahap 4 "pendinginan 5 menit dan istirahat pulang kerumah masing-masing. Dari contoh di atas dapat dilihat kepadatan latihan yang baik dimana dengan waktu 90 menit latihan dilakukan dengan serius dan tidak banyak waktu santai atau istirahatnya. Sehingga dapat menghasilkan latihan yang efektif dan efisien.

Berdasarkan hasil dari pengamatan diatas, peneliti ingin melakukan penelitian dengan "survei efektivitas latihan pada ekstrakurikuler sepak bola di SMP Negeri 4 Dedai".

\section{METODE PENELITIAN}

Metode yang digunakan pada penelitian ini adalah deskriptif kuantitatif dengan metode survei. Populasi pada penelitian ini adalah proses latihan pada ekstrakurikuler sepak bola di SMP Negeri 4 Dedai tahun ajaran 2018/2019 dan sampel yang digunakan dalam penelitian ini adalah proses latihan ekstrakurikuler sepak bola di SMP Negeri 4 Dedai pada semester genap tahun 2018/2019. Teknik pengumpulan data dengan insidental sampling dan alat pengumpulan data dengan cara mengamati dan mencatat proses latihan dari waktu ke waktu. Teknik pengambilan data dalam penelitian ini dengan mengunakan lembar observasi. Adapun obserasi yang dilakukan adalah mengamati proses latihan ekstakurikuler dri waktu ke waktu dari awal latihan hingga proses latihan selesai. Berapa langkah pelaksanaan dan penggunaan instrumen tersebut adalah sebagai berikut : Hidupkan stopwatch sejak awal hingga akhir proses latihan.Memberikan tanda ceklis pada kolom stopwatch sesuai dengan berkurangnya waktu pada stopwacth. Kemudian memberi tanda (X) pada kolom alokasi fokus segera setelah guru atau pelatih menyuruh siswa melakukan aktivitas fisik fokus latihan. Pada saat yang sama dengan menuliskan jumlah siswa yang melakukan latihan dengan fokus pada kolom siswa fokus. Penghitungan jumlah siswa yang melakukan aktivitas fisik fokus tujuan pada menit berikutnya dilakukan segera setelah waktu memasuki menit berikutnya. Penghitungan jumlah siswa fokus tujuan hanya di lakukan manakala pada kolom sebelumnya terdapat tanda (X). Pengambilan data dilakukan sebanyak mungkin hingga data yang dikumppulkan jenuh. Dalam hal ini, proses latihan sudah kembali seperti semula.

\section{Teknik analisis data.}

Setelah data terkumpul dari hasil pengumpulan data maka akan dianalisis meliputi 3 langkah yaitu: Persiapan Kegiatan dalam langkah persiapan ini antara lain: Mengecek kelengkapan data, artinya memeriksa isi instrumen pengumpulan data (termasuk pula kelengkapan lembaran instrume). Mengecek macam isian data.

Tabulasi Kegiatan dalam langkah ini adalah memasukan data kedalam bagan tabel dan pemberian skor terhadap item-item yang perlu diberi skor. Penerapan data sesuai dengan pendekatan penelitian. Berdasarkan pendekatan penelitian atau desain yang diambil maka metode analisis data yang di gunakan dalam penelitian ini adalah dengan melihat jumlah siswa focus dalam proses latihan kemudian dimasukkan dalam rumus sebagai berikut: 


$$
\begin{aligned}
& \text { jumlah ketelibatan siswa } \\
& =\frac{\text { jumlah siswa fokus }}{\text { jumlah siswa }} \times 100
\end{aligned}
$$

\section{HASIL PENELITIAN DAN PEMBAHASAN}

\section{Hasil}

SMP Negeri 4 Dedai terletak di desa Lundang Baru, Kecamatan Dedai, Kabupaten sintang. SMP Negeri 4 Dedai ini mmenyediakan berbagai macam kegiatan ektrakurikulerr yang terbagi dalam ekstrakuikuler olahraga dan ekstrakuriuleer non olahraga. Dalam ekstrakurikuler olahraga ini ada dua jenis ekstrakurikuler olahraga yaitu bola voli dan sepak bola. Untuk sepak bola itu sendiri dilaksanakan satu minggu dua kali, pada hari kamis dan sabtu pada jam $15.00: 16.30$.

Jumlah siswa yang mengikuti ekstrakurikuler sepak bola ini berjumlah 30 siswa. Tetapi saat latihan hanya sekitar 20 siswa yang datang, jumlah siswa yang datang pada saat proses latihan tidak menentu di setiap pertemuan.

Pengambilan data dilakukan dari tanggal 7-23 Februari, dalam satu minggu dua pertemuan, yaitu pada hari kamis dan sabtu dilapangan sepak bola Desa Lundang. Latihan dilaksanakan pada jam 15.00-16.30. Total keseluruhan pertemuan yang dilakukan untuk penelitian ini adalah enam kali pertemuan.
Pengambilan data dalam penelitian ini diperoleh dari hasil mencatat kegiatan yang dilakukan dari waktu ke waktu pada saat proses latihan itu dimulai sampai selesai. Waktu dalam satu kali pertemuan adalah 90 menit. Dalam penelitian ini data yang dibutuhkan adalah data jenuh. Data jenuh yang dimaksud dalam penelitian ini, jika terdapat pengulangan materi dalam proses latihan di pertemuan sebelumnya. Contohnya pada pertemuan pertama materi yang di berikan passing dan materi ini di ulang kembali pada pertemuan berikutnya.

Adapun deskripsi data penelitian berdasarkan tabel menunjukan hasil persentase dari enam pertemuan. Pada pertemuan pertama, total siswa yang hadir berjumlah 16 siswa, dengan rata-rata efektiv 15,6 dengan persentase $97,9 \%$. Pertemuan kedua total siswa yang hadir berjumlah 20 siswa, dengan rata-rata efektiv 19,5 dengan persentase 97,9\%. Pertemuan ketiga total siswa yang hadir berjumlah 14 siswa, dengan rata-rata efektiv 13,3 persentase $95,1 \%$. Pertemuan keempat total siswa yang hadir berjumlah 20 siswa, dengan rata-rata efektiv 19,7 dengan persentase 98,7\%. Pertemuan kelima total siswa yang hadir berjumlah 16 siswa, dengan rata-rata efektiv 15,6 dengan persentase 97,9\%. Pertemuan keenam total siswa yang hadir berjumlah 12 siswa, dengan rata-rata efektiv 11,9 dengan persentase $99,4 \%$. Jadi hasil rata-rata persentase keseluruhannya adalah 15,9 dengan persentase $97,8 \%$ dan hasil ini masuk kedalam kriteria persentase yaitu sangat efektiv.

Tabel 1 Persentase Hasil Efektivitas Siswa

\begin{tabular}{cc}
\hline PERTEMUAN & PERSENTASE \% \\
\hline Pertemuan I & $97,9 \%$ \\
\hline Pertemuan I & $97,9 \%$ \\
\hline Pertemuan I & $95,1 \%$ \\
\hline Pertemuan I & $98,7 \%$ \\
\hline Pertemuan I & $97,9 \%$ \\
\hline Pertemuan I & $99,4 \%$ \\
\hline Rata- Rata & $97,8 \%$ \\
\hline
\end{tabular}




\section{Jurnal Ilmu Keolahragaan Volume II Nomor 1 April 2019}

\section{Oky Anggia, Isti Dwi Puspita Wati, Andika Triansyah}

Tersedia di: http://jurnal.untan.ac.id/index.php/jilo

\section{Pembahasan}

Penelitian ini merupakan survei tentang seberapa besar efektivitas latihan sepak bola pada ekstrakurikuler di SMP Negeri 4 Dedai. Penelitian dilakukan dengan cara mencatat proses latihan dari waktu ke waktu. Total waktu dalam satu pertemuan adalah 90 menit. Bedasarkan hasil penelitian yang telah dipaparkan maka dapat disimpulkan bahwaefektivitas latihan pada ekstrakurikuler sepak bola di SMP Negeri 4 Dedai di pengaruhi oleh. efektivitas latihan. Efektivitas latihan yang dimaksud adalah proses latihan yang berjalan dengan tersusun rapi dan tepat sasaran. Tidak banyak siswa yang diam dalam proses latihan, dan waktu yang habis sia-sia dengan contoh siswa yang sibuk mengambil bola yang di tendang jauh.

Efektivitas adalah kemampuan untuk memilih tujuan yang tepat untuk pencapaian tujuan yang telah ditetapkan (Herlambang, 2013: 18). Sedangkan menurut Hasibuan (2000: 120) tercapainya sasaran atau tujuantujuan dari suatu instansi yang telah ditetapkan sebelumnya. Dalam efektivitas terkandung makna berdaya tepat atau berhasil guna untuk menyebutkan bahwa sesuatu itu telah berhasil dilaksanakan secara sempurna, secara tepat dan target telah tercapai. Selain itu efektiv juga terkandung makna efisien, yaitu berdaya guna untuk menunjukan bila suatu tindakan atau usaha sudah efektif dan ekonomis, baru dikatakan efisiens".

Proses latihan ekstrakurikuler di SMP Negeri 4 Dedai dapat katakan efektiv dan efisien. Latihan yang efektiv akan sangat berpengaruh terhadap prestasi yang diharapkan. latihan yang efektiv akan berdampak positif dan dapat menunjang prestasi yang tinggi. Karena menurut Scheunemann (2008: 17) "Sedangkan prestasi yang tinggi hanya dapat dihasilkan dengan di rencanakan secara sistematis, dilakukan dengan cara kontinyu dan dibawah pengawasan pelatih atau guru yang membimbing".

Tetapi pada kenyataanya dengan proses latihan yang terbilang sangat efektiv, prestasi pada ekstrakurikuler sepak bola di SMP Negeri 4 dedai tergolong sangat rendah. Pencapaian prestasi dipengaruhi oleh beberapa faktor. Menurut Irianto, (2002: 8) "usaha mencapai prestasi merupakan usaha yang multikomplek yang melibatkan banyak faktor baik internal maupun eksternal, kualitas latihan merupakan penopang utama tercapainya prestasi, sedangkan kualitas latihan itu sendiri ditopang oleh faktor internal yakni kemampuan atlet (bakat dan motivasi) serta faktor eksternal". Pelatih juga memiliki peran yang penting dalam keberhasilan pretai yang diraih oleh tim. Karena pelatih memiliki peran dalam penyusunan program latihan dan melaksanakan program sesuai dengan kebutuan tim.

Latihan di SMP 4 Dedai kurang variasi di dalam proses latihan,dari 6 kali pertemuan yang dilakukan,gerakan passing sering sekali dilakukan berulang-ulang di setiap sesi latihan dan pertemuannya sehinggamembuat siswa terkadang jenuh karena sesi latihan yang monoton. Terlihat siswa yang mengalami kesulitan dalam melakukan passing jarak jauh. Siswa masih kesulian dalam mengarahkan bola ke arah temannya dengan jarak yang cukup jauh. Tujuan dalam penelitian ini adalah untuk mengetahui seberapa besar efektivitas latihan pada ekstrakurikuler sepak bola di SMP Negeri 4 Dedai. Sampel yang digunakan dalam penelitian ini adalah proses pada latihan ekstrakurikuler sepak bola di SMP Negeri 4 Dedai.

Proses latihan memiliki kesamaan eperti dalam proses pembelajaran penjas, sehingga Sukadiyanto (2005: 20) pemanasan ada minimal empat macam kegiatan pada tahap pemanasan, anatara lain: (1) aktivitas yang bertujuan untuk menaikkan suhu badan, (2) aktivitas peregangan (strectching), baik pasif maupun yang aktif (kalestenik/balistik), (3) aktivitas senam khusus cabang olaharaganya, dan (4) aktivitas gerak teknik cabang olaharaganya. Pemanasan (warming up) dengan waktu 15-30 menit. Latihan inti Latihan inti bisa terdiri dari beberapa komponen latihan. YaituLatihan Fisik (15 menit) Latihan untuk mengembangkan kelincahan, kecepatan, koordinasi dan keseimbangan. Sebanyak mungkin gunakan bola. Latihan Teknik (20 menit) Latihan teknik tanpa lawan guna memperbaiki kualitas teknik dilanjutkan dengan 
latihan teknik dengan lawan agar lebih realistis (sesuai pertandingan) dan mengundang aspek taktis. Taktik (15 menit) Berbagai permainan lapangan kecil guna mengasah pemahaman bertahan/ menyerang, penguasaan bola, kombinasi membangun serangan dari belakang serta penyelesaian akhir. Game (25 menit), Game 7 vs 7 (dengan kiper 8 vs 8) atau 9 vs 9 dengan menekankan kecepatan bermain. Pendinginan (cool down ) 5-10 menit.

Dalam proses latihan yang terdiri dari 3 tahapan penting tersebut harus dilakukan semua. Ada alasan fisiologi yang tepat mengapa pemain harus melakukan pemanaasn, dan cooldown pada saat sebelum dan setelah latihan. Pemanasan yang cukup sangat diperlukan agar tubuh siap menerima beban latihan yang berat. Peningkatan suhu tubuh akan membuat pembuluh darah akan menjadi lebih fleksibel. Peningkatan denyut nadi akan menyakinkan bahwa oksigen dan sari-sari makanan dapat tercukupi selama aktivitas latihan. Jogging ringan dan stretching harus dilaksanakan untuk menutup latihan hari yang bersangkutan, supaya pemain dapat relax secara fisik dan mental sehabis melaksanakan latihanyang berat tetapi menghasilkan kondisi yang maksimal untuk dapat melanjutkan latihan berikutnya sesuai dengan program pelatih.

Dengan latihan yang sesuai akan membawa dampak yang besar untuk prestasi di sekolah tersebut. Latihan ekstrakurikuler di SMP Negeri 4 Dedai ada beberapa tahapan, dimulai dengan tahap I Latihan dimulai dengan berbaris, berdoa, dan penjelasan dari pelatih (10 menit). Tahap II pemanasan gerakan statis, dinamis dan jogging keliling lapagan sebanyak 3 kali total waktu 15 menit. Tahap III siswa melakukan latihan drill dengan passing jarak dekat dan jauh, latihan mengontrol bola, heading, dan game kucing-kucingan total waktu 25 menit. Selanjutnya game melakukan teknik permainan seperti pemain tengah dan depan melawan pemain belakang dan penjaga gawang total waktu 15 menit. Bermain gawang dua di mana setiap posisi di pilih oleh pelatih dan kedua tim saling berlawanan, total waktu 20 menit, tahap ke IV penutup 5 menit terakhir melakukan pendinginan dan doa untuk kembali ke rumah masing-masing.
Berdasarkan dari hasil penelitian yang telah dilakukan bahwa proses latihan di SMP Negei 4 Dedai termasuk dalam kategoi sangat efektiv sehausnya mampu mempengaruhi dan menunjang prestasi sepak bola di SMP Negeri 4 Dedai tersebut. Namun, pada kenyataannya dari tahun ke tahun prestasi dari ekstakuikuler sepakbola di SMP Negeri 4 Dedai ini mengalami penurunan. Hal tersebut banyak dipengaruhi oleh beberapa faktor, bukan hanya semata-mata dari waktu latihan bagi siswa itu efektif saja. Masih banyak factor lain yang ikut berperan, seperti program latihan, pelatih, sarana dan prasarana. Proses latihan yang dilakukan di lakukan sesuai dengan tujuan dan harapan untuk meraih prestasi. Dalam latihan juga sebaiknya di perlukan banyaknya variasi latihan supaya siswa menjadi tidak jenuh. Dilihat dari waktu, proses latihan sangat efektif. Tetapi jika dilihat dari segi kualitas, masih ada materi yang kurang didalam proses latihanya itu untuk latihan fisiknya. Seharusnya semua komponen. latihan tersebut harus dilaksanakan dengan baik dalam proses latihan. Sehingga, selain menghasilkan proses latihan yang efektif dan efisien, juga bisa mendapatkan prestasi yang diharapkan. Pada pertemuan pertama, total siswa yang hadir berjumlah 16 siswa, dengan rata-rata efektiv 15,6 dengan persentase 97,9\%. Pertemuan kedua total siswa yang hadir berjumlah 20 siswa, dengan rata-rata efektiv 19,5 dengan persentase $97,9 \%$. Pertemuan ketiga total siswa yang hadir berjumlah 14 siswa, dengan rata-rata efektiv 13,3 dengan persentase 95,1\%. Pertemuan keempat total siswa yang hadir berjumlah 20 siswa, dengan rata-rata efektiv 19,7 dengan persentase $98,7 \%$. Pertemuan kelima total siswa yang hadir berjumlah 16 siswa, dengan rata-rata efektiv 15,6 dengan persentase $97,9 \%$. Pertemuan keenam total siswa yang hadir berjumlah 12 siswa, dengan rata-rata efektiv 11,9 dengan persentase 99,4\%. Jadi hasil rata-rata persentase keseluruhannya adalah 15,9 dengan persentase 97,8\% dan hasil ini masuk kedalam kriteria persentase yaitu sangat efektiv. 


\section{SIMPULAN DAN SARAN}

\section{Simpulan}

Berdasarkan dari hasil penelitian dapat disimpulkan mengenai survei efektivitas latihan pada ekstrakurikuler sepak bola di SMP Negeri 4 Dedai. Secara umum berdasarkan hasil penelitian survei efektivitas latihan pada ekstrakurikuler sepak bola di SMP Negeri 4 Dedai secara keseluruhan rata-rata efektivitas latihanya sebesar $97,8 \%$ dengan kriteria sangat efektiv.

\section{Saran}

Dari kesimpulan yang sudah di paparkan maka peneliti memberikan saran yang diharapkan dapat membantu proses latihan agar latihan dapat berjalan dengan efektiv.

Program latihan yang sesuai dengan tujuan ekstrakurikuler di sekolah, agar dapat tercapainya prestasi yang diinginkan sesuai dengan tujuan dari pihak sekolah.

Lebih banyak materi latihan yang bervariasi agar siswa tidak jenuh dalam menjalani proses latihan. Diharapkan dapat diadakan penelitian lanjutan untuk yang berminat, untuk lebih mendalami penelitian yang sudah dilakukan agar dapat bermanfaat untuk membantu jalannya proses latihan menuju prestasi atau tujuan yang diinginkan pihak sekolah.

\section{DAFTAR RUJUKAN}

Adang, S. (2009). Revitalisasi Pengajaran Dalam Pendidikan Jasmani. Bandung: FPOK UPI.

Bompa. (2009). Terjemahan buku Theory and Methodology of Training. Bandung : program pasca sarjana Universitas padjadjaran.

Budiwanto. (2012). Metodologi latihan olahraga. Malang : UM press.

Djoko Pekik (2002). Dasar kepelatihan. Yogyakarta : FIK UNY.

Hasibuan. (2000). Sumber Daya Manusia. Jakarta : PT Bumi Aksara.

Herdiansyah, w. (2011). Mengenal sepak bola. Jakarta Timur : Wadah ilmu.

Herlambang. (2013). Pengantar manajemen. Yogyakarta : Gosyen publishing.

Irianto. (2002). Dasar kepelatihan. Yogyakarta : FIK UNY.

Rahmani, M. (2011). Buku super lengkap olahraga. Jakarta : dunia cerdas.

Suharsimi, A. (2010). Prosedur penelitian ; suatu pendekatan Praktek. Jakarta : Rinenka cipta.

Sugiyono. (2016). Metode Penelitian Pendidikan ( pendekatan kuantitatif, kualitatif, dan $R \& D$ ). Bandung : Afbeta.

Scheunemann. (2008). Dasar-dasar sepak bola modern untuk pemain dan pelatih. Malang : DIOMA.

Sukadiyanto. (2005). Pengantar teori dan melatih fisik. Yogyakarta. 